\title{
Development of pig cloning studies: past, present and future
}

\author{
M. Samiec ${ }^{1}$ \\ National Research Institute of Animal Production, \\ Department of Animal Reproduction \\ 32-083 Balice, Poland
}

(Received 7 November 2003; revised version 2 April 2004; accepted 9 April 2004)

\begin{abstract}
The birth of the first nuclear transfer-derived cloned piglet resulted from the transfer of a nucleus from a 4-cell stage embryo to an enucleated oocyte. Although biotechnological procedures in swine have recently undergone tremendous progress, the efficiency of pig somatic cloning is still lower than in other species of farm animals and, when expressed as a proportion of reconstructed oocytes, it does not exceed an average of 5 to $10 \%$ blastocysts and $1.5 \%$ born piglets. The basic prerequisite for practical application of this method is to improve efficiency. This requires further detailed studies. Development of pig somatic cell cloning was inspired not only by the necessity for quick improvement of the efficiency of the nuclear transfer technique in this species, but above all by its possible practical application for multiplication of transgenic piglets, for use in transplantation medicine and immunology, also pharmacy and animal breeding. A deficit of organs for human allotransplantation became a stimulus to the search for new, alternative sources of grafts. Therefore, a particularly attractive aspect of pig somatic cloning is the possibility of generating large numbers of transgenic pig organs for xenotransplantation. Compatibility with the human ones in size, anatomy, and physiology makes this an attractive proposition.
\end{abstract}

KEY WORDS: pig, embryo cloning, somatic cloning, nuclear transfer, xenotransplantation

\section{INTRODUCTION}

The late 1990s brought many new achievements in animal reproduction biotechnology. These included in vitro maturation and fertilization of oocytes of new mammal species (including wild animal species), improvement of microsurgical

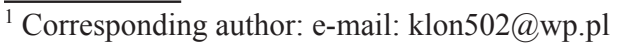


fertilization (mainly intracytoplasmic sperm injection; ICSI) techniques, methods of oocyte cryopreservation and in vitro embryo culture systems. However, achievements in mammalian somatic cloning understandably aroused the greatest interest. Somatic cloning and transgenesis, in particular the combination of both these techniques, are now the research areas with the greatest potential for application. The biological foundations established chiefly over the last ten years or so, make it possible to develop technologies which fulfil the conditions of application, among them the prerequisite of effectiveness. However, the many hopes attached to these methods are not validated by facts.

Since the birth of Dolly, the sheep (Wilmut et al., 1997), when it became clear that mammals can be obtained by transplantation of nuclei derived from cells of adult animals, somatic cloning established itself as a new research direction, becoming, in a comparatively short time, one of the most rapidly developing fields of both animal reproductive biotechnology and experimental embryology. Dolly was the first mammal to be produced by adult individual cloning, and as a consequence the first example of mammalian somatic cloning. For more than a year she was the only animal derived from this method of cloning. Some commentators thought that she was produced accidentally by introducing a nucleus of an undifferentiated cell into the ooplast. Despite all these doubts, however, the production of Dolly inspired and encouraged many researchers to look for new ideas, often with great success. This helped to improve all stages of the cloning procedure and brought somatic cell cloning to the forefront of assisted reproduction technologies (ART) in animals.

\section{SOMATIC CLONING IN VARIOUS SPECIES OF MAMMALS}

The rate of improvement of methods for somatic cell nuclei reprogramming and in methods of reconstructed oocyte activation meant that over five years the somatic cloning technique produced offspring of farm animals such as cattle (Cibelli et al., 1998; Wells et al., 1999; Kato et al., 2000), sheep (McCreath et al., 2000), goats (Baguisi et al., 1999), pigs (Onishi et al., 2000; Polejaeva et al., 2000; Bondioli et al., 2001; Boquest et al., 2002; Yin et al., 2002), mule (Woods et al., 2003) and horse (Galli et al., 2003) and laboratory animals such as the mouse (Wakayama et al., 1998; Ono et al., 2001). The domestic cat (Shin et al., 2002) has also been cloned as have endangered species of free-living animals such as African wild cats (Gomez et al., 2004), gaur (Lanza et al., 2000a) and mouflon (Loi et al., 2001). Although the effectiveness of somatic cell cloning is still very low with only $1-3 \%$ reconstructed oocytes and $10 \%$ on average of embryos fit for transplantation into surrogate recipients, forming neonates, the problems of somatic cloning continue to arouse increasing interest among researchers. The reasons for this are numerous, both intellectual and practical. 
Many studies investigating the somatic cloning of different farm and laboratory animal species confirmed that the high rate of in vitro developmental capacity to the blastocyst stage by reconstructed embryos can only be attained through correct coordination between nucleus donor cell phenotype and cell cycle stage (Campbell and Alberio, 2003). Also important are the efficacies of the exogenous somatic nuclei transplantation procedure for maternal chromosome elimination (recipient oocyte enucleation), the oocyte reconstruction technique and the clonal cybrid (cytoplasmic hybrid) activation system (Kato et al., 2000; Polejaeva et al., 2000; Wakayama and Yanagimachi, 2001; Galli et al., 2002; Roh and Hwang, 2002; Yin et al., 2002; Nagashima et al., 2003; Samiec et al., 2003a,b). At present, the most common embryo reconstruction techniques are nuclear transfer followed by electric pulse fusion of cytoplast (ooplast) with somatic cell (cattle: Cibelli et al., 1998; Wells et al., 1999; Kato et al., 2000; sheep: Wilmut et al., 1997; McCreath et al., 2000; goats: Baguisi et al., 1999; pigs: Koo et al., 2000; Polejaeva et al., 2000; Boquest et al., 2002; Yin et al., 2002) or the use of a suspension of inactivated Sendai virus (HVJ) particles with an accurately defined number of haemagglutination activity units (mice: Kato et al., 1999; Ono et al., 2001). The procedures of microsurgical nuclear transfer, involving both direct karyoplast (cell nucleus with residual, perinuclear protoplasmic "ring" i.e. perikaryon) injection into the cytoplasm of an enucleated oocyte (pigs: Kuhholzer et al., 2000; Onishi et al., 2000; Samiec et al., 2003a,b; Roh and Hwang, 2002; mice: Wakayama et al., 1998; Chung et al., 2002; cattle: Lacham-Kaplan et al., 2000; Galli et al., 2002; horses: Choi et al., 2002), and whole cell intraooplasmic microinjection (pigs: Lee et al., 2003b) are also used frequently.

HYPOTHESIS OF SPECIES-SPECIFIC RESISTANCE OF PIG TO ASSISTED REPRODUCTION TECHNOLOGIES IN THE FIELD OF EXPERIMENTAL EMBRYOLOGY (EMBRYO ENGINEERING)

Of the farm livestock species, pigs (Sus scrofa domesticus L.) have been the least frequent subjects of experimental embryology studies encompassing oocyte and embryo manipulations. This may be due to problems associated with the complex in vitro embryo production (IVP) procedures in this species, the low efficiency of porcine oocyte maturation under in vitro conditions and the weaknesses of in vitro fertilization and embryo in vitro culture (cited by Kikuchi et al., 2002).

\section{The history of porcine embryo and somatic cloning studies}

Nuclear transfer in pigs was first described by Robl and First (1985). In the following years its repeatability was validated by the studies of Prather et al. (1988) and later by obtaining the first piglet as a result of transplantation of 4-cell embryo 
blastomere nuclei into the enucleated Metaphase II (Met II) oocytes (Prather et al., 1989). However, a decade of studies made from then on to improve the efficiency of individual stages of the pig cloning procedure produced little progress. Thus, for many years, the effectiveness of the cloning method, measured both by the rate of reconstructed embryo development to compact morula/blastocyst stages and by percentage of born piglets in relation to the number of nuclear transfers remained at a constant, comparatively low level. Occasionally reports of the production of porcine morulae and blastocysts in vitro appeared (Saito et al., 1992; Terlouw et al., 1992; Nagashima et al., 1997). However, they did not exert a significant influence on increasing either the postimplantation developmental potential of reconstructed clonal embryos or the rate of foetal development to the end of gestation. For almost 11 years a gilt obtained by Prather's team $(1989,1999)$ was the only piglet derived from transplantation into an enucleated, activated Met II oocyte of an embryonic cell nucleus. The failure to confirm this achievement gave rise to many doubts as to the repeatability of the method and many even questioned the reliability of the experiment.

The factor which, for a long time, was thought to be one of the most significant elements restricting the structural remodeling of exogenous cell nuclei, was the onset of embryonic genome transcriptional activity (Koo et al., 2000; Verma et al., 2000). It was believed that from this moment on, the introduced cell nucleus cannot be epigenetically reprogrammed in the cytoplasmic microenvironment of the porcine oocyte (Verma et al., 2000; Rideout III et al., 2001). It turned out that, of the species examined, this view probably holds true only for mice and pigs, in which the initiation of embryonic genome transcriptional activity occurs at very early stages of embryogenesis; the early 2-cell stage (mouse: Schultz, 1993) and the late 4-blastomere stage (pig: Schoenbeck et al., 1992). Transcriptional activation of the embryonic nuclear and mitochondrial genome is associated with maternal to embryonic transition (MET) of genome control. Activation of the embryonic genome was accompanied by reversible (transitional) cleavage-block visible in in vitro culture conditions at 2-cell stage in the mouse and at 4-cell stage in the pig (Viuff et al., 2002). This block is presumably analogous, in this aspect, to the cleavage-block of 8 to 16-cell ovine embryos and 4 to 8 -cell bovine embryos (Dominko et al., 1999). This developmental block can also assume a form of constant and irreversible inhibition of blastomere/cell divisions triggered by incomplete remodeling and reprogramming of cell nuclei in the reconstituted embryos. As a result there is inappropriate changes in gene expression (Daniels et al., 2000; Kang et al., 2001), transcriptional factor (for example Oct-4, Oct-3) activity (Boiani et al., 2002) and pattern of protein synthesis (Daniels et al., 2000), making further preimplantation development of porcine embryos impossible (Koo et al., 2000; Verma et al., 2000; Viuff et al., 2002). A cleavage-block during the third mitotic cycle of reconstructed porcine embryos can be also artificially induced 
by suboptimal in vitro culture conditions, chiefly the inadequate composition of simple, chemically-defined culture media. The suboptimal conditions prevent activation (expression) of many genes as a result of epigenetic modifications of the genome by DNA demethylation and histone acethylation. They also inhibit the synthesis of indispensable proteins which regulate the course of embryonic cell cycles and block the secretion of autocrine or paracrine polypeptide growth factors (Kuhholzer et al., 2000; Rideout III et al., 2001; Viuff et al., 2002). Because of an irreversible developmental block in in vitro cultured porcine nuclear transfer-derived embryos a hypothesis about the limiting effect of the timing of the embryonic genome activation was proposed. It suggests that achieving full development after transplantation of cell nuclei derived from embryos having over four blastomeres is practically impossible. Although a perceived impassable barrier in the form of blastomere cytokinesis inhibition in the in vitro culture of porcine cloned embryos has been overcome, in vitro developmental competences of embryos reconstructed from cell nuclei of embryos, which exceeded the stage of transcriptional activation of its own genome, were still very limited. Saito et al. (1992) and Terlouw et al. (1992) demonstrated that 1/8-1/16 blastomere cell nuclei are able, only to a small extent, to direct in vitro development of porcine clonal cybrids to the blastocyst stage ( 7 and $4.5 \%$ of blastocysts obtained, respectively). However, Nagashima et al. (1997) reported that $15 \%$ of embryos reconstituted with morula cell nuclei developed to blastocyst stage. In this last experiment, recipient cytoplasts were derived from oocytes preactivated with DC pulses. However, while porcine primordial germ cells were fused with electrically preactivated or non-activated Met II oocytes, the embryos produced were unable to develop beyond the 4-cell stage (Liu et al., 1995). In vitro developmental potential of embryos reconstructed with in vitro cultured somatic cell nuclei was also very low. The blastocyst formation (cavitation) rates among the embryos reconstituted with nuclei of foetal fibroblast cells in vitro cultured to $100 \%$ confluence state (contact inhibition of migration and cell growth) or serum starved (exposed to trophic deprivation) for 9-13 days, before microinjecting directly into ooplasts, or fusing with enucleated oocytes, were just 4-5\% (Tao et al., 1999a,b). In turn, Miyoshi et al. (2000a) obtained only 3\% blastocysts from oocytes reconstructed with cell nuclei of permanent embryonic stem cell-like cell lines established from inner cell mass (ICM) cells of hatched porcine blastocysts.

Against a background of all these studies conducted over the last decade, the achievement of full development, to the end of gestation, by only one embryo reconstructed using a four-cell blastomere nucleus, at the postembryonic genome transcriptional activation stage, is a significant accomplishment (Prather et al., $1989,1999)$. The reasons for this extremely low efficiency of embryo and somatic cloning of pigs were unknown and aroused many reservations, especially since it was impossible to repeat the results obtained by Prather et al. $(1989,1999)$ in 
any later experiments. More and more doubts appeared also with regard to problems related to the inhibitory effect of comparatively early initiation of genome transcriptional activity on the in vitro development of porcine cloned embryos. Arguments in support of "the inhibitory theory" would make it easier to question the efficacy of Prather et al.'s report $(1989,1999)$, but these arguments tended to evaporate when the in vitro developmental block of porcine nuclear transfer-derived embryos was overcome. They evaporated even further with the production of clones of mouse (Mus musculus L.), a species in which genome transcriptional activity begins at an earlier stage of embryogenesis (2-cell stage) than in pig, from nuclei of embryonic cells at post-transcriptional stage (Cheong et al., 1993; Kwon and Kono, 1996), and also from cumulus cell nuclei (Wakayama et al., 1998). These spectacular achievements brought conclusive evidence against the preceding hypothesis. At present, the earlier failures in the field of pig cloning are attributed not only to incomplete epigenetic reprogramming of somatic nuclei genome but also to inadequate systems of reconstituted porcine oocyte activation (Koo et al., 2000; Onishi et al., 2000; Polejaeva et al., 2000; Boquest et al., 2002).

It is beyond any doubt that the boom in studies of somatic cloning in other livestock species such as cattle, sheep, goats, which has occurred since the crucial discovery by Wilmut et al. (1997) has finally broken the "silence" of more than a decade concerning pig cloning. Thus the years 2000-2002 witnessed a real explosion of studies in nuclear transfer of pigs.

\section{STEPS OF SOMATIC CELL NUCLEAR TRANSFER PROCEDURE AFFECTING EFFI- CIENCY - IMPORTANT AND UNIQUE ASPECTS OF PIG CLONING TECHNOLOGY}

\section{Cloning competence of various somatic cell types}

In the studies on pig somatic cloning over the last four years, nuclear donor cells derived from several different types of tissues collected from both foetuses and adult animals of both sexes have been used. Somatic cell nuclear transfer was used to produce a total of 90 live piglets from in vitro cultured: foetal fibroblast cells (Onishi et al., 2000; Park et al., 2001c; Boquest et al., 2002; Dai et al., 2002; De Sousa et al., 2002; Lai et al., 2002a,b; Walker et al., 2002; Hyun et al., 2003; Ramsoondar et al., 2003; Yin et al., 2003), skin fibroblasts (Bondioli et al., 2001), ear-derived fibroblasts (Park et al., 2002; Lee et al., 2003b), mural granulosa cells (Polejaeva et al., 2000), cells of an indefinite phenotype isolated from foetuses and their genital ridges (Betthauser et al., 2000), and heart cells (probably cardiomyocytes; Yin et al., 2002). In the experiments aimed at determining the in vitro developmental abilities of reconstructed porcine embryos to compact morula and blastocyst stages, foetal fibroblasts (Tao et al., 1999a,b; Koo et al., 2000; Uhm et al., 2000; Verma et al., 2000; Kuhholzer et al., 2000, 2001; Lai et al., 2001; Park et al., 2001b) or cumulus/ 
mural granulosa cells (Cheong et al., 2000; Uhm et al., 2000; Park et al., 2001a; Martinez Diaz et al., 2002; Nagashima et al., 2002; Lee et al., 2003b; Samiec et al., 2003a,b) as well as ear skin fibroblasts of adult animals (Miyoshi et al., 2001; Roh and Hwang, 2002) were most often used as a source of donor nuclei.

In contradistinction to the pig, in cattle and mice the successful (resulting in the birth of cloned offspring) tests were carried out with nuclear transfer of cells derived from many types of tissues, organs and body parts of adult individuals or foetuses, but the phenotype was easy to define only in the case of follicular (cumulus and mural granulosa) cells (Kato et al., 1998; Wakayama et al., 1998; Wells et al., 1998, 1999; Skrzyszowska et al., 2000), colostrum-derived mammary gland epithelial cells (Kishi et al., 2000), leukocytes (Galli et al., 1999), B and T cells (bone marrow-dependent and thymus-dependent lymphocytes; Hochendlinger and Jaenish, 2002), immature Sertoli cells (Ogura et al., 2000), oviductal epithelial and uterine epithelial (endometrium) cells (Kato et al., 1998, 2000), adult skin fibroblast cells (Vignon et al., 1998; Zakhartchenko et al., 1999a; Kato et al., 2000; Kishi et al., 2000; Kubota et al., 2000), foetal fibroblast cells from muscle and skin biopsies (Cibelli et al., 1998; Vignon et al., 1998; Zakhartchenko et al., 1999b), and neural cells from the cerebral cortex of foetuses (Yamazaki et al., 2001). In the majority of cases, when somatic cells were collected from explants of ear tissue (Kato et al., 2000), tail tip (Wakayama and Yanagimachi, 1999), muscle (Musculus longissimus dorsi) tissue (Shiga et al., 1999; Skrzyszowska et al., 2000), mammary gland (udder; Wilmut et al., 1997; Zakhartchenko et al., 1999a; Kato et al., 2000), gonads, foetal lungs, liver and spleen tissue (Kato et al., 2000; Wakayama and Yanagimachi, 2001), their phenotype was difficult to define. However, it can be supposed that in all these cases donor nuclei were fibroblast and fibrocyte cells. Nuclei of other somatic cells of definite phenotype, such as: neurons (brain neural cells; Wakayama et al., 1998), macrophages (Wakayama and Yanagimachi, 2001), mature Sertoli cells (sustentocytes; Wakayama et al., 1998), or also kidney cells (Kato et al., 2000) supported development of reconstructed embryos only to early gestation stages. It is not understood if the differences in developmental competences of porcine oocytes reconstituted by transplantation of different types of cells arise from different susceptibilities of their nuclei to chromatin remodeling and genome reprogramming in the cytoplasmic environment of Met II oocytes, or from other factors such as imperfection of the present enucleation methods, the nuclear transfer (oocyte reconstruction) techniques and the clonal cybrid activation procedures.

Coordination between donor cell type and cell cycle stage - effect of cell cycle stage synchronization

To specify the cell cycle stage and also donor cell type that allows efficient genetic modification of somatic cells and easy epigenetic genome reprogramming 
or to establish such clonal cell lines is a crucial issue in porcine somatic cloning. That is why in the experiments by Kano (2002) and Nagashima et al. (2003), the pre-adipocyte cell lines derived from dedifferentiated mature adipocytes of the subcutaneous adipose tissue of adult pigs have recently been tested for nuclear transfer. Cell cycle synchronization at $\mathrm{G} 0 / \mathrm{G} 1$ stages by differentiation induction with a combined isobutyl-methylxanthine, dexamethasone, insulin treatment is unique to the progenitor cells of adipocytes. The cells immediately entered the G0 (quiescence) phase by artificially induced cytodifferentiation, with higher effectiveness of donor nuclei synchronization than the other standard methods such as trophic deprivation, cell contact inhibition at confluency state or chemically assisted cell cycle coordination. Moreover, the frequency of apoptosis is low in the cell subpopulations synchronized by cytodifferentiation induction compared with other synchronization systems, including serum starvation, in vitro culture to total confluency point, and chemical treatment of donor cells with specific or non-specific cyclin dependent kinase (CDK) inhibitors such as roscovitine, butyrolactone or olomoucine, which are G1/G0 phase inductors (Nagashima et al., 2003). In pig somatic cloning technology, a source of donor nuclei is more frequently the cells whose mitotic cycle is transiently inhibited at G2/M phase borderline (checkpoint) by artificial synchronization with chemical mediators from a group of kariokinetic spindle microtubule polimerization inhibitors (Lai et al., 2001, 2002b; Miyoshi et al., 2001). Partial biodegradation of microtubular cytoskeleton as a result of somatic cell incubation in a colchicine (Lai et al., 2002b) or nocodazole solution (Miyoshi et al., 2001) causes reversible blocking of the cell division cycle at metaphase or slowing down of cell proliferating activity. In turn a decrease of mitotic cell division rate and delay, and consequently greater uniformity of the cell growth cycle rate reduces the degree of asynchrony in entering the G2/M stage in the majority of cells of the in vitro cultured subpopulation (clonal line). Almost complete coordination of the phase of the donor cell or karyoplast nuclear cycle and ooplast cytoplasmic cycle increases the ability of somatic nuclei for correct remodeling of the spatial conformation of chromatin and the epigenetic reprogramming of the genome inside the cytoplasmic microenvironment of the Met II recipient oocyte.

\section{Reconstruction techniques of enucleated oocytes}

Introduction of cell nuclei into the enucleated recipient cells, apart from enucleation, is the most significant stage of the somatic cloning procedure. In pig somatic cloning, one of the following two experimental systems is now being used. In the first system cell nuclei at G1 or G0 stage are introduced into enucleated, nonactivated Met II oocytes and simultaneously obtained clonal nuclear-cytoplasmic hybrids are activated (Uhm et al., 2000; Verma et al., 2000; Kuhholzer et al., 2001; Park et al., 2001b; Dai et al., 2002; Lai et al., 2002a,b; Hyun et al., 2003). In the 
second system cell nuclei at G1, G1/G0 or G2/M stages are introduced into Met II ooplasts, which are activated 30 minutes to several hours (3-4 hours at the most) after nuclear transfer (Betthauser et al., 2000; Kuhholzer et al., 2000; Onishi et al., 2000; Bondioli et al., 2001; Lai et al., 2001; Park et al., 2001a; Boquest et al., 2002; De Sousa et al., 2002; Hyun et al., 2003; Lee et al., 2003b; Ramsoondar et al., 2003; Samiec et al., 2003a,b). Microsurgical transfer of somatic nuclei can be an alternative method for clonal nuclear-cytoplasmic hybrid reconstruction (Tao et al., 1999; Kuhholzer et al., 2000; Onishi et al., 2000; Uhm et al., 2000; Lai et al., 2001; Park et al., 2001a; Nagashima et al., 2002; Samiec et al., 2003a,b) prior to cell fusion induced in the electric field. In terms of the molecular mechanisms of nuclear chromatin rearrangement, this has beneficial influences on epigenetic reprogramming and structural remodeling of exogenous genetic material. Also recent studies on pig cloning (Roh and Hwang, 2002) proved the effectiveness of piezo-driven microinjection of ear-derived fibroblast karyoplasts. In this study the percentage of viable oocytes after the cell nuclei transplantation procedure did not differ significantly from that of clonal cybrids reconstituted by the electrofusion method. In addition, there is no significant difference in pseudo-pronuclear formation rate, cleavage activity, blastocyst formation rate or cell numbers in blastocysts between groups of porcine clonal cybrids reconstituted with ear skin derived fibroblast nuclei by electrofusion and piezo-driven nuclear injection (Roh and Hwang, 2002). On the other hand, in the studies carried out by Nagashima et al. (2003), using foetal fibroblast cell nuclei simultaneous comparison between two nuclear transfer methods (ooplast-donor cell complex electrofusion and intracytoplasmic piezo-electric microinjection into enucleated oocytes) revealed clear differences in the pattern of nuclear remodeling and developmental potential of embryos to blastocyst stage as well as in the morphological quality of the clonal blastocysts as measured by total cell number. However, considering the results of the majority of the studies for nuclear transfer in farmed livestock species (Lacham-Kaplan et al., 2000; Ogura et al., 2000; Park et al., 2001a; Wakayama and Yanagimachi, 2001; Galli et al., 2002), it can be concluded that intraooplasmic injection of karyoplasts prepared from cells at G0/G1 or G2/M stages of cell cycle could also increase considerably the total efficiency of somatic cloning in pigs and other mammalian species.

\section{Artificial activation of reconstructed oocytes}

An extremely important factor influencing the developmental potential of reconstructed porcine oocytes is their activation procedure. In pig somatic cloning technology, the most often used activating stimuli are physical agents such as DC pulses (Onishi et al., 2000; Polejaeva et al., 2000; Bondioli et al., 2001; Lai et al., 2001; Dai et al., 2002; De Sousa et al., 2002; Yin et al., 2002; Hyun et al., 2003; 
Lee et al., 2003b; Samiec et al., 2003a,b; Ramsoondar et al., 2003), or chemical agents such as ionomycin (Betthauser et al., 2000; Boquest et al., 2002; Roh and Hwang, 2002; Yin et al., 2002; Hyun et al., 2003; Samiec et al., 2003a,b) or thimerosal in combination with dithiothreitol (Tao et al., 1999a,b; Kuhholzer et al., 2000). The current intensive studies on improving artificial activation methods of porcine cytoplasmic hybrids (cybrids) are chiefly aimed at optimizing technical parameters of the electrical field such as strength, duration of DC pulses, number of pulses and time interval between them. Alternatively, and more often, they are aimed at associating an activating stimulus, most frequently ionomycin, $\mathrm{Ca}$ ionophore $\mathrm{A} 23187$ or DC pulses with agents such as 6-dimethylaminopurine (6-DMAP; Betthauser et al., 2000; Boquest et al., 2002; Roh and Hwang, 2002; Yin et al., 2002; Hyun et al., 2003) and butyrolactone (Yin et al., 2002) which block the activity of cyclin-dependent protein kinases (CDKs) or agents that inhibit protein synthesis (translation). Here an example is cycloheximide (CHXM; Cheong et al., 2000; Martinez Diaz et al., 2002; Yin et al., 2002; Lee et al., 2003b; Samiec et al., 2003a,b).

\section{THE POSSIBILITIES OF PRACTICAL APPLICATION OF PIG SOMATIC CLONING IN GENETIC MODIFICATION (TRANSGENESIS)}

While, in other species of farm animals, somatic cloning led to numerous clones, represented by individuals of both sexes, in the pig (Sus scrofa domesticus L.) obtaining the reconstructed blastocysts in the in vitro culture system was for many years a problem. Until recently, production of pig genetic copies was impossible, mainly because porcine somatic cell nuclei are for some unknown reason more resistant to reprogramming than somatic cell nuclei of other species of animals. At the present stage of investigations the efficiency of somatic cloning technology in pigs is still lower than in other species of farm animals and as a rule, in relation to the number of the reconstructed oocytes it does not exceed an average of 5 to $10 \%$ blastocysts and $1.5 \%$ piglets born. The basic prerequisite for practical application of this technology is to ensure improved efficiency, which requires carrying out further detailed studies. Development of the studies on pig somatic cloning, especially in recent years, was inspired not only by the necessity of quick improvement in the efficiency of the nuclear transfer technique in this species, but above all by the possibility of its practical application for multiplication of transgenic piglets, on the grounds of important implications for transplantation medicine, immunology and pharmacy. The recent reports of successful pig cloning with the use of nuclei of non-transfected differentiated cells as DNA donors (Betthauser et al., 2000; Onishi et al., 2000; Boquest et al., 2002; De Sousa et al., 2002; Walker et al., 2002) and production of transgenic pigs (expressing gene encoding enhanced green fluorescent protein) by nuclear 
transfer of in vitro transfected somatic cells (Park et al., 2001c, 2002; Lai et al., 2002b; Hyun et al., 2003) may indicate the approaching phase of intensive tests on transplantation of genetically-transformed porcine organs into non-human primates and eventually human recipients (pig-to-human-xenotransplantation). So too does the production of cloned piglets generated from cultured skin fibroblasts derived from a H-transferase ( $\alpha$-1,2-fucosylosyltransferase; $\alpha$-1,2-FT) transgenic boar (Bondioli et al., 2001). Unfortunately, attempts at transplanting vascularized pig organs always result in their hyperacute vascular rejection (HAR; Joziasse and Oriol, 1999). It seems that only organs of transgenic pigs, which would have the expression of genes "humanizing" their cells, would constitute desirable material for xenogeneic transplants. A major hindrance to the common use of pig organs in medicinal transplantology is immunological incompatibility, above all by way of species specific major histocompatibility complexes (MHC): human (HLA; human leukocyte antigens) and porcine (SLA; swine leukocyte antigens). However, a deficit of organs for human allotransplantation became a stimulus for a search of new, alternative sources of grafts. It has been postulated for a long time that genetically-modified pigs can provide (considering the high fertility and prolificacy of this species) a virtually unlimited source of xenograft donors. Xenotransplantation of porcine organs is also an attractive option because of their compatible size, physiology and anatomy (Joziasse and Oriol, 1999). The use of targeted exogenous DNA construct introduction (locus-specific genetic modification; Figure 1) by chosen transfection methods of in vitro cultured populations (clonal lines) of porcine somatic cells, and then fusion (or intraooplasmic microinjection) of so prepared donor nuclei with in vitro or in vivo matured recipient oocytes could lead to numerous pig clones. These could produce, for example, human MHC antigens (HLA), various immunosuppressive proteins, or inhibitors of cytotoxicity of complement system (such as human C3 convertase decay-accelerating factor; CD55/DAF), or "masked" epitopes by competitive inhibition of $\alpha$-1,3-galactosyltransferase ( $\alpha-1,3-G T)$ by $\alpha-1,2$-fucosylosyltransferase (Joziasse and Oriol, 1999; Thomson et al., 2003). It could also lead to pig clones with such genes inactivated by "knock-out" technique (homologous recombination; Figure 1). This involves encoding enzymes which catalyse the addition of different antigenic determinant fragments (xenogeneic oligosaccharide residues) to the plasma membrane glycoproteins and glycolipids (for example $\alpha-1,3-G T$ allele, locus GGTA1), that are responsible for hyperacute vascular rejection (HAR) of xenografts (xenogeneic transplants), as a result of immunoreaction with human preformed xenoreactive antibodies (mainly anti-Gal antibodies, directed against galactosyl- $\alpha-1,3$-galactose epitopes on the surface of porcine endothelial graft cells; Joziasse and Oriol, 1999; Galili, 2001; Thomson et al., 2003). Transgenesis (with application of gene targeting; Figure 1), in conjuction with somatic cloning, could provide, in the 
near future, a basis for the generation and multiplication of a pig population with such genetically transformed ("humanized") immunological system and blocked expression of many epitopes. This population would provide a source of xenograft donors with substantially extended survival rate (increased resistance to HAR) in primate recipients. The cloning of all livestock species (Schnieke et al., 1997; Cibelli et al., 1998; Baguisi et al., 1999; Keefer et al., 2001) by somatic cell nuclear transfer provides an alternative means of targeted disruption or deletion of genes in mammals. The obtaining of cloned sheep with targeted insertions at the ovine $\alpha 1(\mathrm{I})$-procollagen (COLIA1) locus showed that viable animals can be produced by nuclear transfer with gene-targeted cultured foetal fibroblasts (McCreath et al., 2000). The $\alpha-1,3-G T$ gene and the prion protein (PrP) gene have recently been successfully deleted in ovine foetal fibroblasts and in foetuses cloned from these donor cell nuclei genetically modified by homologous recombination (Denning et al., 2001). Although no viable offspring resulted, these experiments showed that disruption of $\alpha-1,3-\mathrm{GT}$ gene using somatic nuclei transplantation techniques is feasible in farm animals. Dai et al. (2002) and Lai et al. (2002) have recently conducted the targeted mutagenesis (Figure 1) of one allele of the GGTA1 locus in porcine foetal fibroblasts and produced a total of nine live female $\alpha-1,3-$ GT knock-out piglets by nuclear transfer of these cells. In turn, Ramsoondar et al. (2003) have created a total of six genetically engineered male piglets that possess an $\alpha-1,3-$ GT knock-out allele, but four of them express additionally a randomly inserted human $\mathrm{H}$-transferase $(\alpha-1,2-\mathrm{FT})$ transgene. This was the first study to use Southern blot analysis to demonstrate the disruption of the $\alpha-1,3$-GT gene in somatic $\alpha$-1,2-FT-transgenic pig cells (foetal fibroblasts) before they were used for nuclear transfer (Ramsoondar et al., 2003). The generation of homozygous $\alpha-1,3$-GT knock-out boars with the $\alpha$-1,2-FT-transgenic background is underway and will be unique (Phelps et al., 2003; Ramsoondar et al., 2003). This approach intends to combine the $\alpha-1,3-G T$ knock-out genotype with a ubiquitously expressed $\alpha-1,2$-fucosylosyltransferase transgene producing the universally tolerated $\mathrm{H}$ antigen on cell membrane surface. Such genetic modification of cloned pigs may prove to be more effective than the $\alpha-1,3-\mathrm{GT}$ null phenotype alone in overcoming hyperacute rejection and delayed xenograft rejection, because the galactosyl- $\alpha-1,3$-galactose epitopes can be downregulated by competitive inhibition between $\alpha-1,3-\mathrm{GT}$ and $\alpha-1,2-\mathrm{FT}$ for the common acceptor substrate N-acetyl lactosamine (Joziasse and Oriol, 1999; Galili, 2001; Ramsoondar et al., 2003; Thomson et al., 2003). More recently, the second allele of $\alpha-1,3-$ GT gene has also been inactivated by selection of a T-to-G single point mutation at the second base of exon 9, which resulted in knock-out of the gene. Four healthy gilts with double knock-out of $\alpha-1,3-$ GT gene (one allele of GGTA1 locus by targeted disruption and the second by selection procedure of point mutation) were obtained by nuclear transfer (Phelps et al., 2003). In contradistinction 


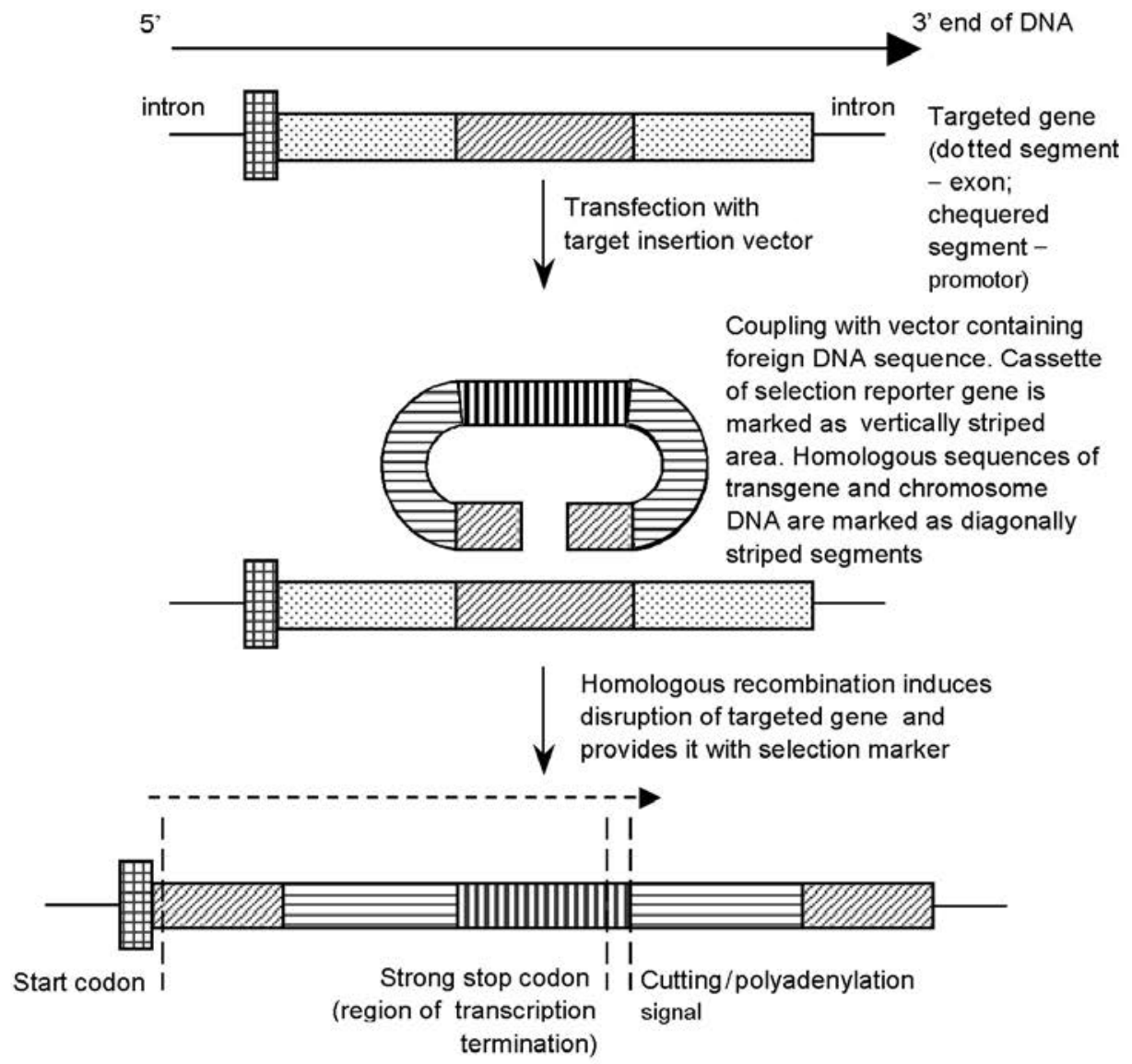

Gene knock-out by targeted disruption of its exon sequence (insertion gene traps) as a result of transgene integration ${ }^{1}$. Broken arrow indicates a direction of reporter gene transcription

${ }^{1}$ As a result of insertion of the gene construct carrying null mutation into chromosome sequence, homology region (diagonally striped segment) is repaired and duplicated. Replicated DNA segments are situated on both sides of reporter gene (the so-called flanking sequences. In order to inactivate the chromosome gene, homology region should be situated inside the coding segment of targeted gene. In turn selection marker gene should build into the region of exon. Reporter gene must be fitted out with the properly functioning region of transcription termination and the polyadenylation signal

Figure 1. Schema of targeted mutagenesis by technique of insertion inactivation (knock-out) allele of certain gene 
to $\alpha-1,3-$ GT-semideficient cloned pigs, complete removal of galactosyl- $\alpha-1,3-$ galactose epitopes in the organs of $\alpha-1,3-$ GT-deficient cloned piglets may be the critical step toward the success of xenotransplantation.

Recapitulating, somatic cell nuclear transfer in pigs is the most promising technology to achieve the targeted disruption of the $\alpha-1,3-\mathrm{GT}$ gene, in that donor cells can be genetically transformed before nuclear transplantation using existing technologies. The major limitation to the genetic modification of donor cell nuclei is the length of time, for which transfected cells must be cultured in vitro to allow selection, clonal line growth, and genetic testing preceding nuclear transfer. Undoubtedly the ability of these cells to undergo a second cycle of gene targeting to remove a second allele could be diminished. However, genetically manipulated donor cells can be used to produce a cloned foetus or adult animal, thus providing cells that can be used for additional rounds of targeted mutagenesis (knock-out) to delete or disrupt a second allele, or to target additional genes encoding the immunoproteins responsible for hyperacute or acute rejection of xenogeneic grafts (Thomson et al., 2003; Wang and Zhou, 2003). The prospect of transgenesis and somatic cell nuclear transfer combination also opens up new possibilities for production of animal bioreactors synthesizing and supplying, in blood and natural (physiological) body excreta and secretions (urine, milk), human proteins and hormones. These products include different biopharmaceuticals/therapeutic proteins (human haemoglobin in porcine erythrocytes, human insulin, VIII and IX blood coagulation/clotting factor, human antithrombin III, $\alpha$-1-antitrypsin and others; Swanson et al., 1992; Sharma et al., 1994; Schnieke et al., 1997; Baguisi et al., 1999; McCreath et al., 2000; Keefer et al., 2001; Lee et al., 2003b).

\section{FUTURE GOALS, CHALLENGES AND HURDLES TO SOMATIC CLONING IN PIGS AND OTHER MAMMAL SPECIES}

Effective pig somatic cloning, avoiding the sexual reproduction pathway, creates a possibility of providing numerous monogenetic offspring derived not only from transgenic individuals, but also from adult (postpubertal) animals selected for outstanding (remarkable) traits of breeding (genetic) and productive value. It is commonly believed that somatic cloning could accelerate the rate of genetic progress, producing in a short time many identical animals with the most desirable, accurately defined genotypes. However, it is often forgotten that the animals obtained by somatic cloning are only "genetic copies" of the genome contained in the nucleus of the donor cell, and not an accurate phenotypic replica of the animal that donated the cells. Omitted from the effects on identity of produced clones are such factors as: genetic and chromosome mutations of nuclear and mitochondrial (mt) DNA, oocytic and somatic mtDNA hybridization (heteroplasmy). Also omitted are maternal effects caused by recipient surrogates, e.g., intrauterine environ- 
ment and steroid hormonal profile of recipient females. In addition and, not without significance are the costs of somatic cloning, which at present are completely unprofitable for breeders. Nevertheless, taking into account the technology of in vitro culture and establishment of permanent cell lines from different types of somatic cells isolated from adult individuals or porcine foetuses, the quantity of donor cell nuclei subpopulations, and consequently the quantity of clones could be considerably increased. This aim can also be attained by the use of multiple cloning procedures involving serial nuclear transfer (Galli et al., 1999; Wells et al., 1999; Zakhartchenko et al., 1999b; Polejaeva et al., 2000; Ono et al., 2001).

Analysis of nuclear-cytoplasmic interactions in the hybridic cells produced by nuclei transplantation of differentiated cells into "apparently undifferentiated" oocyte cytoplasm enables better understanding of cytodifferentiation regulatory mechanisms. It may also contribute to broader understanding of cell and organism aging mechanisms. For genetic improvement of pigs, somatic cloning - even if it becomes as efficient as sexual reproduction - will be of little use, as it reduces population variability. Cloned individuals are of course "delayed" twin siblings of their own progenitory prototype. That is why multiplication of them decreases, in the long term, genetic progress. However, as has already been mentioned, the technology promotes the multiplication of productively-valuable individuals, and consequently allows also for standardization of farm animal-derived products, which in the context of market requirements, will have growing significance. Genetically modified pig cloning for biomedical purposes to obtain biopreparations or organs suitable in medicine transplantology, or to create cell (gene) therapy foundations for a number of serious monogenic diseases, is seen as a service to humanity. At present the work involved in solving the specific problems of somatic cloning is arduous. The majority of these problems however are likely to be solved in the near future. This will make cloning technology safe, i.e. the cases of individuals born with developmental abnormalities, as a result of its use, will not be more frequent than in natural reproduction. Somatic cloning, in spite of many spectacular achievements, brings more and more questions, which remain yet unanswered. It is beyond any doubt that the technical possibilities which enabled the production of cloned animals, exceeded understanding of the associated biological conditions, in particular the molecular aspects of the technology. While tremendous progress in the field of somatic cloning has been achieved during the past few years with the birth of numerous offspring of different mammal species worldwide, the overall efficiency remains low. The current high incidence of pre- and/or postimplantation embryonic, foetal as well as perinatal abnormalities limits the practical applications of somatic cloning and contributes to the negative perception of this assisted reproduction technology (ART) to society. The aims are to understand the mechanisms involved in cell nucleus reprogramming, which can lead to the pathologic syndromes. 
Molecular mechanisms of remodeling/reprogramming of donor nuclear genome in the somatic cloning of mammals - main problems limiting efficiency of nuclear transfer

The basic assumption of somatic cloning is the fact that the donor cell nucleus has to be completely reprogrammed by specific oocytic agents in such a way as to support the development of the reconstituted embryo to term. It is now believed that the chief cause, both of low developmental potential of nuclear transferred embryos and foetuses, and the lethal anatomo- and histopathological defects in the foetal and extrafoetal (placental) tissues as well as immune dysfunction is abnormal adaptation of transplanted somatic nuclei to the biochemical conditions of the oocyte cytoplasmic microenvironment (Hill et al., 2000; Kikyo and Wolffe, 2000; Dean et al., 2001, 2003; De Sousa et al., 2001; Ono et al., 2001; Surani, 2001; Chavatte-Palmer et al., 2002; Heyman et al., 2002). In other words, it is their incomplete and/or defective remodeling/reprogramming in the cytoplasm of enucleated oocyte (ooplast), that gives rise to problems. Moreover, no consistent definition of cell nuclei reprogramming has been provided so far. It can be assumed, however, that this process comprises all the changes to which cell nuclei are subjected after introduction into ooplasts, and which lead to structural and functional assimilation of these nuclei to zygote pronuclei. The remodeling of introduced cell nuclei would then include consequent transformations, occurring within somatic chromatin, of its spatial conformation collectively defined as denomination of constitutional and metabolic rearrangement of nuclear genetic apparatus (Han et al., 2003; Reik et al., 2003; Shi et al., 2003a). As has been mentioned, the somatic nuclei which are remodeled after artificial activation of reconstructed oocytes, and arrested at Met II meiotic division block, not only resemble morphologically but also imitate cytophysiologically, interphase nuclei which are formed after oocyte fertilization. That is why in the nuclear transfer embryos at 1-cell stage are very often known as pseudopronuclei or apparent pronuclei as well as spurious pronuclei and presumptive/pretended pronuclei. But, in spite of undergoing the series of ultrastructural and biochemical changes such as nuclear envelope break-down (NEBD), dispersion of nucleoli, premature chromosome condensation (PCC) before oocyte activation, and also chromosome decondensation, nuclear envelope restoration as well as intensive nucleologenesis and nuclear swelling, after oocyte activation, these pseudopronuclei are not yet fully reprogrammed. They are therefore unable to direct the entire pre- and/or postimplantation development of clonal embryos and foetuses (Kang et al., 2001a,b; Renard et al., 2002; Vignon et al., 2002; Campbell and Alberio, 2003; Cezar et al., 2003). It therefore follows from this that functional reprogramming of remodeled somatic nuclei is not a one-step (a single-phase) biochemical process, but rather a multi-stage one, and it takes place in the blastomere nuclei in cycles of all preimplantation phases of embryo- 
genesis. At the present stage of investigations it is assumed that a complete and correct reprogramming process would affect epigenetic modifications of the somatic genome leading to frequency changes in the degree of expression of several embryonic genes as a result of silencing (repression) or enhancing (stimulation) of their transcriptional activity (Kono, 1997; Campbell, 1999b; Rideout III et al., 2001; Inoue et al., 2002; Bortvin et al., 2003; Mann et al., 2003).

Successful cloning of animals requires epigenetic reprogramming of the differentiated state of the donor cell nucleus to a totipotent embryonic state. It means that the donor nuclei must cease its own program of gene expression and restore a particular program of the embryonic genome expression (transcriptional activity) necessary for normal development (Dean et al., 2001; Surani, 2001; Shi et al., 2003a). Epigenetic modifications, such as donor genomic DNA methylation and its likely interaction with histone deacetylation and methylation, have been considered to be candidates regulating nuclear reprogramming (Reik et al., 2001; Rideout III et al., 2001; Bortvin et al., 2003). In early stages of clonal mammalian embryo development two-step changes in the somatic tissue-specific pattern of donor genomic DNA methylation occur, which are related to epigenetic nuclear reprogramming. The most dramatic changes in the DNA methylation level occur throughout the preimplantation development of cloned embryos and during gametogenesis of cloned foetuses (Latham, 1999; Cezar et al., 2003). During early embryonic development, the overall methylation level of somatic genetic apparatus sharply decreases and reaches a low point at the blastocyst stage. The process of epigenetic reprogramming in early NT embryos erases gamete-specific methylation patterns inherited from the parental genome of nuclear donor cells. This somatic DNA-wide demethylation process may be crucial for the formation of pluripotent stem cells that are important for the later development at the gastrulation stage. During the postimplantation phase of embryogenesis and fetogenesis, a wave of de novo methylation of genetic material takes place and most of the genomic DNA is methylated at defined developmental timepoints (Kang et al., 2001a,b; Reik et al., 2001; Enright et al., 2003). Another demethylation/ remethylation unique cycle of epigenetic reprogramming occurs throughout gametogenesis and is necessary for resetting of parental donor genome imprinting (Inoue et al., 2002; Dean et al., 2003; Lee et al., 2003a). Expression profiles of several imprinted genes (among others insulin-like growth factor 2/Igf2 gene, Igf2 receptor/Igf $2 r$ gene, $H 19$ foetal liver mRNA gene, small nuclear ribonucleoprotein N/Snrpn gene) have been analysed in both cloned and in vitro-produced (IVP) pre- and postimplantation embryos and foetuses of such mammal species as mouse, cattle and sheep. Imprinting of parental genome is correlated with the methylation of normally unmethylated 5'-cytidine-3'-monophosphate-5'-guanosine-3' $(\mathrm{CpG})$ islands in the differently methylated regions (DMRs) of the uniparentally exprimed alleles of the nuclear DNA genes. Genes expressed exclu- 
sively from the maternal allele (i.e. paternally methylated) such as $\operatorname{Ig} f 2 r$ or $H 19$ should be represented by a higher relative abundance of transcriptional products in parthenogenetic embryos whereas paternally expressed genes (i.e. maternally methylated) such as $\operatorname{Ig} f 2$ should be correlated with a higher gene expression in IVP and cloned embryos carrying one paternal and one maternal allele (Young et al., 2001; Inoue et al., 2002; Lee et al., 2003a; Mann et al., 2003; Ogawa et al., 2003; Shi et al., 2003a). Aberrations in the methylation status (i.e. inappropriate epigenetic reprogramming) and faithful expression of imprinted genes, which are developmentally important, are thought to be involved in the Large Offspring Syndrome (LOS). The LOS is frequently observed in offspring derived from IVP and cloned embryos which have been exposed to specific culture conditions (the use of foetal bovine serum/FBS-supplemented medium or coculture system) before their transfer into recipient females (Young et al., 1998, 2001; Eggan et al., 2001; Chavatte-Palmer et al., 2002; Inoue et al., 2002; Han et al., 2003; Lee et al., 2003a; Reik et al., 2003). It causes important late foetal losses not only in IVP embryos, but also the considerable decrease of the overall efficiency of cloning in mice and ruminants (Dean et al., 2001, 2003; Chavatte-Palmer et al., 2002; Heyman et al., 2002). In this syndrome, perinatal deaths are associated with abnormal placental development which involve, among others, hydrops/hydroallantois, placental hypertrophy, anomalies in the formation of spongiotrophoblasts and the labyrinthine layers in murine placentas, enlarged edematous placentomes in reduced numbers in bovine and ovine placentas. Another typical malformations of the in vitro-derived cloned embryos which are related to LOS are excessive foetal growth and thereby increased birth weight as well as asynchronous growth of organs (Cibelli et al., 1998; Wakayama et al., 1998; Young et al., 1998, 2001; Hill et al., 1999, 2000; Lanza et al., 2000b; McCreath et al., 2000; De Sousa et al., 2001; Eggan et al., 2001; Ono et al., 2001; Chavatte-Palmer et al., 2002; Heyman et al., 2002). There is higher incidence of LOS in clones produced from somatic and embryonic stem (ES) cells compared with clones produced from non-cultured embryonic cells and in all clones compared with IVP embryos (Young et al., 2001; Heyman et al., 2002; Inoue et al., 2002; Han et al., 2003; Ogawa et al., 2003). This raises the question of whether the high incidence of LOS-related gestation losses after cloning is mainly due to in vitro culture conditions or to associated reprogramming effects of the imprinting memory of donor genome in nuclear transferred and IVP embryos. The recent studies show that increasing evidence has pointed towards epigenetic deregulation of imprinted genes due to incomplete or abnormal resetting of donor DNA methylation and/or histone acetylation patterns during embryo and foetal development (Reik et al., 2001, 2003; Enright et al., 2003; Lee et al., 2003a; Han et al., 2003; Mann et al., 2003). It has been reported that epigenetic alteration of the imprinted (maternally expressed) Igf $2 r$ and $H 19$ DMR segments and thereby abnormal expression (i.e. decreased transcription or 
suppression) of the corresponding genes have been detected in both sheep LOS foetuses derived from IVP embryos and mouse LOS foetuses produced by nuclear transfer of somatic or embryonic stem cells. In contrast, the transcription of $P 0$, which is a placental-specific transcript variant of $\operatorname{Igf} 2$, increased at more than four times the control in placenta of cloned mouse foetuses at day 12.5 of gestation. Control embryos were produced by pronuclear transfer, in which Met II oocytes were fertilized in vitro and the resultant pronuclei were transferred into enucleated eggs of allogeneic origin (Young et al., 2001; Inoue et al., 2002; Mann et al., 2003; Ogawa et al., 2003). By contrast, expression of $\operatorname{Igf} 2$ gene was not changed in foetal tissues of clones. Rather than acting to signal the presence of the insulinlike growth factor to the cell the IGF2 receptor is believed to remove and destroy IGF2. In these conditions the peripheral concentration of IGF2 would be expected to be higher and acting to increase growth of cloned foetuses (Latham, 1999; Eggan et al., 2001; Rideout III et al., 2001; Young et al., 2001; Chavatte-Palmer et al., 2002; Inoue et al., 2002; Lee et al., 2003a; Mann et al., 2003; Ogawa et al., 2003; Reik et al., 2003; Shi et al., 2003a).

Recapitulating, the dynamic, several-step epigenetic modifications of donor genome after somatic cell nuclear transfer (i.e. clonal cybrid reconstruction) include among others, processes of chromatin structure remodeling (Dean et al., 2001; Rideout III et al., 2001; Vignon et al., 2002; Bortvin et al., 2003), global changes in overall DNA methylation status (Kikyo and Wolffe, 2000; Archer et al., 2003; Cezar et al., 2003), uniparental (monoallelic) expression of imprinted genes (Latham, 1999; Dean et al., 2003; Mann et al., 2003), restoration of telomere length (Lanza et al., 2000b; Tian et al., 2000; Cui et al., 2003; Shi et al., 2003b), and also X chromosome inactivation in female clones (Eggan et al., 2000; Wrenzycki et al., 2002). All these events, which take place synchronously with donor nuclear cycle progression in the cytoplasmic microenvironment of embryonic cells, lead to global rearrangement of the somatic genetic apparatus, at various stages of pre- and postimplantation development (Campbell, 1999a,b; Surani, 2001; Campbell and Alberio, 2003; Cezar et al., 2003; Enright et al., 2003). The remodeling and reprogramming of somatic nuclear apparatus is a result of interaction of factors accumulated in the nucleoplasm and attached to the chromatin, configured in the form of metaphase plate in consequence of appropriate rearrangement of its spatial structure and nucleosome repression, with protein factors of recipient cell (oocyte) cytoplasm. This shows that these processes, crucial for mammalian somatic cloning, are not a direct effect of conformance of the exogenous genetic material to cytophysiological conditions of Met II ooplast. That is why the nucleus of a somatic cell has a tendency towards minimizing the degree of expression of its developmental program after its introduction into foreign cytoplasm of allogenic origin (Campbell, 1999a; Rideout III et al., 2001; Renard et al., 2002; Campbell and Alberio, 2003). In turn, the low contribution of realizing the somatic genetic program in the preimplantation 
development of reconstituted embryos should be revealed in conservation through donor nuclear apparatus the competence for easy adaptation to the meiotic to mitotic transition of cell cycle control of activated clonal cybrids (Kono, 1997; Campbell, 1999a,b; Fissore et al., 1999; Vignon et al., 2002). On the other hand, this process is related to the compatibilities in interactions of donor nucleus with the recipient cytoplasm (i.e. coordination of nuclear and ooplasmic events) after embryo reconstruction (Campbell and Alberio, 2003). However, the abilities of transplanted cell nuclei to fully direct the developmental program of reconstructed embryos are most likely the result of correct course of molecular mechanisms accompanying both nuclear chromatin remodeling and reprogramming of somatic cell genome. Proper rearrangement of exogenous genetic apparatus induces only the program of active action donor genomic DNA on the hybridic clonal embryo cytoplasm and on the mitochondrial DNA (mtDNA) molecules of heteroplasmic origin and from ooplasmic (maternal) inheritance (Cummins, 2001a,b; Garesse and Vallejo, 2001; Brüggerhoff et al., 2002; Dean et al., 2003; Shi et al., 2003a).

Based on these findings, expression profiles of different genes of somatic nuclear genome that are important for embryonic and foetal development or survival rate should be studied more closely in the early stages of cloned embryos. So far, however, the precise mechanism for the epigenetic anomalies in the nuclear transferred embryos remains unclear. The characterization of more parameters that affect the developmental competences of the embryos helps the current nuclear transfer technology to identify its problems and to address what should be done to resolve them. It is reasonable that preimplantation cloned embryos are one of the most valuable materials for studies on epigenetic reprogramming. Therefore, to improve the efficiency of the present cloning methods, more extensive investigations should be performed on molecular mechanisms underlying the reprogramming of donor cell genome during early embryogenesis.

\section{REFERENCES}

Archer G.S., Dindot S., Friend T.H., Walker S., Zaunbrecher G., Lawhorn B., Piedrahita J.A., 2003. Hierarchical phenotypic and epigenetic variation in cloned swine. Biol. Reprod. 69, 430-436

Baguisi A., Behboodi E., Melican D.T., Pollock J.S., Destrempes M.M., Cammuso C., Williams J.L., Nims S.D., Porter C.A., Midura P., Palacios M.J., Ayres S.L., Denniston R.S., Hayes M.L., Ziomek C.A., Meade H.M., Godke R.A., Gavin W.G., Overstrom E.W., Echelard Y., 1999. Production of goats by somatic cell nuclear transfer. Nat. Biotechnol. 17, 456-461

Betthauser J., Forsberg E., Augenstein M., Childs L., Eilertsen K., Enos J., Forsythe T., Golueke P., Jurgella G., Koppang R., Lesmeister T., Mallon K., Mell G., Misica P., Pace M., Pfister-Genskow M., Strelchenko N., Voelker G., Watt S., Thompson S., Bishop M., 2000. Production of cloned pigs from in vitro systems. Nat. Biotechnol. 18, 1055-1059

Boiani M., Eckardt S., Scholer H.R., McLaughlin K.J., 2002. Oct 4 distribution and level in mouse clones: consequences for pluripotency. Gene. Dev. 16, 1209-1219 
Bondioli K., Ramsoondar J., Williams B., Costa C., Fodor W., 2001. Cloned pigs generated from cultured skin fibroblasts derived from a H-transferase transgenic boar. Mol. Reprod. Dev. 60, 189-195

Boquest A.C., Grupen C.G., Harrison S.J., McIlfatrick S.M., Ashman R.J., d'Apice A.J.F., Nottle M.B., 2002. Production of cloned pigs from cultured fetal fibroblast cells. Biol. Reprod. 66, 1283-1287

Bortvin A., Eggan K., Skaletsky H., Akutsu H., Berry D.L., Yanagimachi R., Page D.C., Jaenisch R., 2003. Incomplete reactivation of Oct4-related genes in mouse embryos cloned from somatic nuclei. Development 130, 1673-1680

Brüggerhoff K., Zakhartchenko V., Wenigerkind H., Reichenbach H.-D., Prelle K., Scernthaner W., Alberio R., Kuchenhoff H., Stojkovic M., Brem G., Hiendleder S., Wolf E., 2002. Bovine somatic cell nuclear transfer using recipient oocytes recovered by ovum pick-up: effect of maternal lineage of oocyte donors. Biol. Reprod. 66, 367-373

Campbell K.H.S., 1999a. Nuclear transfer in farm animal species. Cell Dev. Biol. 10, 245-252

Campbell K.H.S., 1999b. Nuclear equivalence, nuclear transfer, and the cell cycle. Cloning 1, 3-15

Campbell K.H.S., Alberio R., 2003. Reprogramming the genome: role of the cell cycle. Reproduction 61, Suppl., 477-494

Cezar G.G., Bartolomei M.S., Forsberg E.J., First N.L., Bishop M.D., Eilertsen K.J., 2003. Genomewide epigenetic alterations in cloned bovine fetuses. Biol. Reprod. 68, 1009-1014

Chavatte-Palmer P., Heyman Y., Richard C., Monget P., LeBourhis D., Kann G., Chilliard Y., Vignon X., Renard J.P., 2002. Clinical, hormonal, and hematologic characteristics of bovine calves derived from nuclei from somatic cells. Biol. Reprod. 66, 1596-1603

Cheong H.T., Ikeda K., Martinez Diaz M.A., Katagiri S., Takahashi Y., 2000. Development of reconstituted pig embryos by nuclear transfer of cultured cumulus cells. Reprod. Fert. Develop. $12,15-20$

Cheong H.T., Takahashi Y., Kanagawa H., 1993. Birth of mice after transplantation of early cell - cycle stage embryonic nuclei into enucleated oocytes. Biol. Reprod. 48, 958-963

Choi Y.H., Love C.C., Chung Y.G., Varner D.D., Westhusin M.E., Burghardt R.C., Hinrichs K., 2002. Production of nuclear transfer horse embryos by piezo-driven injection of somatic cell nuclei and activation with stallion sperm cytosolic extract. Biol. Reprod. 67, 561-567

Chung Y.G., Mann M.R.W., Bartolomei M.S., Latham K.E., 2002. Nuclear-cytoplasmic "tug of war" during cloning: effects of somatic cell nuclei on culture medium preferences of preimplantation cloned mouse embryos. Biol. Reprod. 66, 1178-1184

Cibelli J.B., Stice S.L., Goluece P.J., Kane J.J., Jerry J., Blackwell C., Ponce de Leon F.A., Robl J.M., 1998. Cloned transgenic calves produced from nonquiescent fetal fibroblasts. Science 280, 1256-1258

Cui W., Wylie D., Aslam S., Dinnyes A., King T., Wilmut I., Clark A.J., 2003. Telomerase-immortalized sheep fibroblasts can be reprogrammed by nuclear transfer to undergo early development. Biol. Reprod. 69, 15-21

Cummins J.M., 2001a. Mitochondria: potential roles in embryogenesis and nucleocytoplasmic transfer. Hum. Reprod. 7, 217-228

Cummins J.M., 2001b. Cytoplasmic inheritance and its implications for animal biotechnology. Theriogenology 55, 1381-1399

Dai Y., Vaught T.D., Boone J., Chen S.-H., Phelps C.J., Ball S., Monahan J.F., Jobst P.M., McCreath K.J., Lamborn A.E., Cowell-Lucero J.L., Wells K.D., Colman A., Polejaeva I.A., Ayares D.L., 2002. Targeted disruption of the $\alpha 1,3$-galactosyltransferase gene in cloned pigs. Nat. Biotechnol. 20, 251-255

Daniels R., Hall V., Trounson A.O., 2000. Analysis of gene transcription in bovine nuclear transfer embryos reconstructed with granulosa cell nuclei. Biol. Reprod. 63, 1034-1040 
Dean W., Santos F., Reik W., 2003. Epigenetic reprogramming in early mammalian development and following somatic nuclear transfer. Semin. Cell Dev. Biol. 14, 93-100

Dean W., Santos F., Stojkovic M., Zakhartchenko V., Walter J., Wolf E., Reik W., 2001. Conservation of methylation reprogramming in mammalian development: aberrant reprogramming in cloned embryos. Proc. Natl. Acad. Sci. USA 98, 13734-13738

Denning C., Burl S., Ainslie A., Bracken J., Dinnyes A., Fletcher J., King T., Ritchie M., Ritchie W.A., Rollo M., de Sousa P., Travers A., Wilmut I., Clark J., 2001. Deletion of the $\alpha(1,3)$ galactosyl transferase (GGTA1) gene and the prion protein (PrP) gene in sheep. Nat. Biotechnol. 19, 559-562

De Sousa P., Dobrinsky J.R., Zhu J., Archibald A.L., Ainslie A., Bosma W., Bowering J., Bracken J., Ferrier P.M., Fletcher J., Gasparrini B., Harkness L., Johnston P., Ritchie M., Ritchie W.A., Travers A., Albertini D., Dinnyes A., King T.J., Wilmut I., 2002. Somatic cell nuclear transfer in the pig: control of pronuclear formation and integration with improved methods for activation and maintenance of pregnancy. Biol. Reprod. 66, 642-650

De Sousa P.A., Walker S., King T.J., Young L.E., Harkness L., Ritchie W.A., Travers A., Ferrier P., Wilmut I., 2001. Evaluation of gestational deficiencies in cloned sheep fetuses and placentae. Biol. Reprod. 65, 23-30

Dominko T., Mitalipova M., Haley B., Beyhan Z., Memili E., McKusick B., First N.L., 1999. Bovine oocyte cytoplasm supports development of embryos produced by nuclear transfer of somatic cell nuclei from various mammalian species. Biol. Reprod. 60, 1496-1502

Eggan K., Akutsu H., Hochedlinger K., Rideout III W., Yanagimachi R., Jaenisch R., 2000. X-chromosome inactivation in cloned mouse embryos. Science 290, 1578-1581

Eggan K., Akutsu H., Loring J., Jackson-Grusby L., Klemm M., Rideout W.M., Yanagimachi R., Jaenisch R., 2001. Hybrid vigor, fetal overgrowth, and viability of mice derived by nuclear cloning and tetraploid embryo complementation. Proc. Natl. Acad. Sci. USA 98, 6209-6214

Enright B.P., Kubota C., Yang X., Tian X.C., 2003. Epigenetic characteristics and development of embryos cloned from donor cells treated by trichostatin A or 5-aza-2'-deoxycytidine. Biol. Reprod. 69, 896-901

Fissore R.A., Long Ch.R., Duncan R.P., Robl J.M., 1999. Initiation and organization of events during the first cell cycle in mammals: applications in cloning. Cloning 1, 89-100

Galili U., 2001. The $\alpha$-Gal epitope (Gal $\alpha 1-3$ Gal $\beta 1-4 G l c N A c-R)$ in xenotransplantation. Biochimie $83,557-563$

Galli C., Duchi R., Moor R.M., Lazzari G., 1999. Mammalian leukocytes contain all the genetic information necessary for the development of a new individual. Cloning 1, 161-170

Galli C., Lagutina I., Crotti G., Colleoni S., Turini P., Ponderato N., Duchi R., Lazzari G., 2003. Pregnancy: a cloned horse born to its dam twin. Nature 424, 635

Galli C., Lagutina I., Vassiliev I., Duchi R., Lazzari G., 2002. Comparison of microinjection (piezoelectric) and cell fusion for nuclear transfer success with different cell types in cattle. Cloning Stem Cells 4, 189-196

Galli C., Lazzari G., 2003. In vitro production of embryos in farm animals. Short oral communication about production of the first cloned horse - mare named "Prometea", Invited lecture. In: Proceedings of $19^{\text {th }}$ Scientific Meeting of the European Embryo Transfer Association, Rostock (Germany), pp. 93-102

Garesse R., Vallejo C.G., 2001. Animal mitochondrial biogenesis and function: a regulatory cross-talk between two genomes. Gene 263, 1-16

Gomez M.C., Pope C.E., Giraldo A.M., Lyons L., Harris R.F., King A., Cole A., Godke R.A., Dresser B.L., 2004. Birth of African wild cat cloned kittens. Reprod. Fert. Develop. 16, 141 (Abstr.)

Han Y.M., Kang Y.K., Koo D.B., Lee K.K., 2003. Nuclear reprogramming of cloned embryos produced in vitro. Theriogenology 59, 33-44 
Heyman Y., Chavatte-Palmer P., LeBourhis D., Camous S., Vignon X., Renard J.P., 2002. Frequency and occurrence of late-gestation losses from cattle cloned embryos. Biol. Reprod. 66, 6-13

Hill J.R., Long C.R., Looney C.R., Winger Q.A., Spencer T.E., Bazer F.W., Burghardt R.C., Westhusin M.E., 2000. Placental abnormalities in first trimester somatic cell cloned fetuses. Theriogenology 53, 218 (Abstr.)

Hill J.R., Roussel A.J., Cibelli J.B., Edwards J.F., Hooper N.L., Miller M.W., Thompson J..A., Looney C.R., Westhusin M.E., Robl J.M., Stice S.L., 1999. Clinical and pathological features of cloned transgenic calves and fetuses (13 case studies). Theriogenology 51, 1451-1465

Hochendlinger K., Jaenish R., 2002. Monoclonal mice generated by nuclear transfer from mature B and T donor cells. Nature advance online publication, 10 February (DOI 10.1038/nature 718)

Hyun S., Lee G., Kim D., Kim H., Lee S., Nam D., Jeong Y., Kim S., Yeom S., Kang S., Han J., Lee B., Hwang W., 2003. Production of nuclear transfer-derived piglets using porcine fetal fibroblasts transfected with the enhanced green fluorescent protein. Biol. Reprod. 69, 1060-1068

Inoue K., Kohda T., Lee J., Ogonuki N., Mochida K., Noguchi Y., Tanemura K., Kaneko-Ishino T., Ishino F., Ogura A., 2002. Faithful expression of imprinted genes in cloned mice. Science 295, 297

Joziasse D.H., Oriol R., 1999. Xenotransplantation: the importance of the Gal 1 1,3Gal epitope in hyperacute vascular rejection. Biochim. Biophys. Acta 1455, 403-318

Kang Y.-K., Koo D.-B., Park J.-S., Choi Y.-H., Chung A.-S., Lee K.-K., Han Y.-M., 2001a. Aberrant methylation of donor genome in cloned bovine embryos. Nat. Genet. 28, 173-177

Kang Y.-K., Koo D.-B., Park J.-S., Choi Y.-H., Kim H.-N., Chang W.-K., Lee K.-K., Han Y.-M., 2001 b. Typical demethylation events in cloned pig embryos. Clues on species-specific differences in epigenetic reprogramming of a cloned donor genome. J. Biol. Chem. 276, 39980-39984

Kano K., 2002. Establishment of preadipocyte cell lines derived from dedifferentiated mature adipocyte of mammalian and avian. J. Cell Sci. 115 (in press)

Kato Y., Tani T., Tsunoda Y., 2000. Cloning of calves from various somatic cell types of male and female adult, newborn and fetal cows. J. Reprod. Fertil. 120, 231-237

Kato Y., Yabuuchi A., Motosugi N., Kato J., Tsunoda Y., 1999. Developmental potential of mouse follicular epithelial cells and cumulus cells after nuclear transfer. Biol. Reprod. 61, 1110-1114

Keefer C.L., Baldassarre H., Keyston R., Wang B., Bhatia B., Bilodeau A.S., Zhou J.F., Leduc M., Downey B.R., Lazaris A., Karatzas C.N., 2001. Generation of dwarf goat (Capra hircus) clones following nuclear transfer with transfected and nontransfected fetal fibroblasts and in vitro matured oocytes. Biol. Reprod. 64, 849-856

Kikuchi K., Onishi A., Kashiwazaki N., Iwamoto M., Noguchi J., Kaneko H., Akita T., Nagai T., 2002. Successful piglet production after transfer of blastocyst produced by a modified in vitro system. Biol. Reprod. 66, 1033-1041

Kikyo N., Wolffe A.P., 2000. Reprogramming nuclei: insights from cloning, nuclear transfer and heterokaryons. J. Cell Sci. 113, 11-20

Kishi M., Itagaci Y., Takakura R., Imamura M., Sudo T., Yoshinari M., Tanimoto M., Yasue H., Kashima N., 2000. Nuclear transfer in cattle using colostrum - derived mammary gland epithelial cells and ear - derived fibroblast cells. Theriogenelogy 54, 675-684

Kono T., 1997. Nuclear transfer and reprogramming. Rev. Reprod. 2, 74-80

Koo D.-B., Kang Y.-K., Choi Y.-H., Park J.S., Han S.-K., Park I.Y., Kim S.-U., Lee K.-K., Son D.S., Chang W.-K., Han Y.-M., 2000. In vitro development of reconstructed porcine oocytes after somatic cell nuclear transfer. Biol. Reprod. 63, 986-992

Kubota C., Yamakuchi H., Todoroki J., Mizoshita K., Tabara N., Barber M., Yang X., 2000. Six cloned calves produced from adult fibroblast cells after long-term culture. Proc. Natl. Acad. Sci. USA 97, 990-995 
Kühholzer B., Hawley R.J., Lai L., Kolber-Simonds D., Prather R.S., 2001. Clonal lines of transgenic fibroblast cells derived from the same fetus result in different development when used for nuclear transfer in pigs. Biol. Reprod. 64, 1695-1698

Kühholzer B., Tao T., Machaty Z., Hawley R.J., Greenstein J.L., Day B.N., Prather R.S., 2000. Production of transgenic porcine blastocysts by nuclear transfer. Mol. Reprod. Dev. 56, 145-148

Kwon O.Y., Kono T., 1996. Production of identical sextuplet mice by transferring metaphase nuclei from four-cell embryos. Proc. Natl. Acad. Sci. USA, Develop. Biol. 93, 13010-13013

Lacham-Kaplan O., Diamente M., Pushett D., Lewis I., Trounson A., 2000. Developmental competence of nuclear transfer cow oocytes after direct injection of fetal fibroblast nuclei. Cloning 2, 55-62

Lai L., Kolber-Simonds D., Park K.-W., Cheong H.-T., Greenstein J.L., Im G.-S., Samuel M., Bonk A., Rieke A., Day B.N., Murphy C.N., Carter D.B., Hawley R.J., Prather R.S., 2002a. Production of $\alpha$ 1,3-galactosyltransferase knockout pigs by nuclear transfer cloning. Science 295, 1089-1092

Lai L., Park K.W., Cheong H.T., Kuhholzer B., Samuel M., Bonk A., Im G.S., Rieke A., Day B.N., Murphy C.N., Carter D.B., Prather R.S., 2002b. Transgenic pig expressing the enhanced green fluorescent protein produced by nuclear transfer using colchicine-treated fibroblasts as donor cells. Mol. Reprod. Dev. 62, 300-306

Lai L., Tao T., Machaty Z., Kühholzer B., Sun Q.-Y., Park K.-W., Day B.N., Prather R.S., 2001. Feasibility of producing porcine nuclear transfer embryos by using G2/M-stage fetal fibroblasts as donors. Biol. Reprod. 65, 1558-1564

Lanza R.P., Cibelli J.B., Diaz F., Moraes C.T., Farin P.W., Farin C.E., Hammer C.J., West M.D., Damiani P., 2000a. Cloning of an endangered species (Bos gaurus) using interspecies nuclear transfer. Cloning 2, 79-90

Lanza R.P., Cibelli J.B., Blackwell C., Cristofalo V.J., Francis M.K., Baerlocher G.M., Mak J., Schertzer M., Chavez E.A., Sawyer N., Lansdorp P.M., West M.D., 2000b. Extension of cell life-span and telomere length in animals cloned from senescent somatic cells. Science 288, 665-669

Latham K.E., 1999. Epigenetic modification and imprinting of the mammalian genome during development. Curr. Top. Dev. Biol. 43, 1-49

Lee J., Inoue K., Ono R., Ogonuki N., Kohda T., Kaneko-Ishino T., Ogura A., Ishino F., 2003a. Erasing genomic imprinting memory in mouse clone embryos produced from day 11.5 primordial germ cells. Development 129, 1807-1817

Lee J.-W., Wu S.-C., Tian X.C., Barber M., Hoagland T., Riesen J., Lee K.-H., Tu C.-F., Cheng W.T.K., Yang X., 2003b. Production of cloned pigs by whole-cell intracytoplasmic microinjection. Biol. Reprod. 69, 995-1001

Liu L., Moor R.M., Laurie S., Notarianni E., 1995. Nuclear remodeling and early development in cryopreserved, porcine primordial germ cells following nuclear transfer into in vitro - matured oocytes. Int. J. Dev. Biol. 39, 639-644

Loi P., Ptak G., Barboni B., Fulka J., Cappai P., Clinton M., 2001. Genetic rescue of an endangered mammal by cross-species nuclear transfer using post-mortem somatic cells. Nat. Biotechnol. 19, 962-964

Mann M.R.W., Chung Y.G., Nolen L.D., Verona R.I., Latham K.E., Bartolomei M.S., 2003. Disruption of imprinted gene methylation and expression in cloned preimplantation stage mouse embryos. Biol. Reprod. 69, 902-914

Martinez Diaz M.A., Ikeda K., Takahashi Y., 2002. Effects of cycloheximide treatment and interval between fusion and activation on in vitro development of pig nuclear transfer embryos. Reprod. Fert. Develop. 14, 191-197

McCreath K.J., Howcroft J., Campbell K.H.S., Colman A., Schnieke A.E., Kind A.J., 2000. Production of gene targeted sheep by nuclear transfer from cultured somatic cells. Nature 405, 1066-1067 
Miyoshi K., Rzucidło S.J., Gibbons J.R., Arat S., Stice S.L., 2001. Development of porcine embryos reconstituted with somatic cells and enucleated metaphase I and II oocytes matured in a proteinfree medium. BMC Dev. Biol. 1, 12

Miyoshi K., Taguchi Y., Sendai Y., Hoshi H., Sato E., 2000. Establishment of a porcine cell line from in vitro-produced blastocysts and transfer of the cells into enucleated oocytes. Biol. Reprod. 62 , 1640-1646

Nagashima H., Ashman R.J., Nottle M.B., 1997. Nuclear transfer of porcine embryos using cryopreserved delipated blastomeres as donor nuclei. Mol. Reprod. Dev. 48, 339-343

Nagashima H., Fujimura T., Takahagi Y., Kurome M., Wako N., Ochiai T., Esaki R., Kano K., Saito S., Okabe M., Murakami H., 2003. Development of efficient strategies for the production of genetically modified pigs. Theriogenology 59, 95-106

Nagashima H., Kurihara T., Wako N., Ochiai T., Kurome M., Mizuno K, Kano K., Saito S., Murakami H., 2002. In vitro development of porcine nuclear transfer embryos reconstructed by intracytoplasmic microinjection of cumulus cell nuclei into in vitro matured oocytes. J. Reprod. Develop. 48, 121-129

Ogawa H., Ono Y., Shimozawa N., Sotomaru Y., Katsuzawa Y., Hiura H., Ito M., Kono T., 2003. Disruption of imprinting in cloned mouse fetuses from embryonic stem cells. Reproduction $126,549-557$

Ogura A., Inoue K., Ogonuki N., Noguchi A., Takano K., Nagano R., Suzuki O., Lee J., Ishino F., Matsuda J., 2000. Production of male cloned mice from fresh, cultured and cryopreserved immature Sertoli cells. Biol. Reprod. 62, 1579-1584

Onishi A., Iwamoto M., Akita T., Mikawa S., Takeda K., Awata T., Hanada H., Perry A.C.F., 2000. Pig cloning by microinjection of fetal fibroblast nuclei. Science 289, 1188-1190

Ono Y., Shimozawa N., Ito M., Kono T., 2001. Cloned mice from fetal fibroblast cells arrested at metaphase by a serial nuclear transfer. Biol. Reprod. 64, 44-50

Park K.-W., Kühholzer B., Lai L., Machaty Z., Sun Q.-Y., Day B.N., Prather R.S., 2001a. Development and expression of the green fluorescent protein in porcine embryos derived from nuclear transfer of transgenic granulosa-derived cells. Anim. Reprod. Sci. 68, 111-120

Park K.-W., Lai L., Cheong H.-T., Im G.-S., Sun Q.-Y., Wu G., Day B.N., Prather R.S., 2001b. Developmental potential of porcine nuclear transfer embryos derived from transgenic fetal fibroblasts infected with the gene for the green fluorescent protein: comparison of different fusion/activation conditions. Biol. Reprod. 65, 1681-1685

Park K.-W., Cheong H.-T., Lai L., Im G.-S., Kuhholzer B., Bonk A., Samuel M., Rieke A., Day B.N., Murphy C.N., Carter D.B., Prather R.S., 2001c. Production of nuclear transfer-derived swine that express the enhanced green fluorescent protein. Anim. Biotechnol. 12, 173-181

Park K.-W., Lai L., Cheong H.-T., Cabot R., Sun Q.-Y., Wu G., Rucker E.B., Durtschi D., Bonk A., Samuel M., Rieke A., Day B.N., Murphy C.N., Carter D.B., Prather R.S., 2002. Mosaic gene expression in nuclear transfer-derived embryos and the production of cloned transgenic pigs from ear-derived fibroblasts. Biol. Reprod. 66, 1001-1005

Phelps C.J., Koike C., Vaught T.D., Boone J., Wells K.D., Chen S.H., Ball S., Specht S.M., Polejaeva I.A., Monahan J.A., Jobst P.M., Sharma S.B., Lamborn A.E., Garst A.S., Moore M., Demetris A.J., Rudert W.A., Bottino R., Bertera S., Trucco M., Starzl T.E., Dai Y., Ayares D.L., 2003. Production of alpha 1,3-galactosyltransferase-deficient pigs. Science 299, 411-414

Polejaeva J.A., Chen S.-H., Vaught T.D., Page R.L., Mullins J., Ball S., Dai Y., Boone J., Walker S., Ayares D.L., Colman A., Campbell K.H.S., 2000. Cloned pigs produced by nuclear transfer from adult somatic cells. Nature 407, 86-90

Prather R.S., Sims M.M., First N.L., 1988. Nuclear transplantation in the early porcine embryo. Theriogenology 29, 290 (Abstr.) 
Prather R.S., Sims M.M., First N.L., 1989. Nuclear transplantation in early pig embryo. Biol. Reprod. 41, 414-418

Prather R.S., Tao T., Machaty Z., 1999. Development of the techniques for nuclear transfer in pigs. Theriogenology 51, 487-498

Ramsoondar J.J., Machaty Z., Costa C., Williams B.L., Fodor W.L., Bondioli K.R., 2003. Production of $\alpha 1,3$-galactosyltransferase-knockout cloned pigs expressing human $\alpha 1,2$-fucosylosyltransferase. Biol. Reprod. 69, 437-445

Reik W., Dean W., Walter J., 2001. Epigenetic reprogramming in mammalian development. Science 293, 1089-1093

Reik W., Santos F., Dean W., 2003. Mammalian epigenomics: reprogramming the genome for development and therapy. Theriogenology 59, 21-32

Renard J.P., Zhou Q., LeBourhis D., Chavatte-Palmer P., Hue I., Heyman Y., Vignon X., 2002. Nuclear transfer technologies: between successes and doubts. Theriogenology 57, 203-222

Rideout III W.M., Eggan K., Jaenish R., 2001. Nuclear cloning and epigenetic reprogramming of the genome. Science 239, 1093-1098

Robl J.M., First N.L., 1985. Manipulation of gametes and embryos. J. Reprod. Fertil. 33, Suppl., 101-114

Roh S., Hwang W.-S., 2002. In vitro development of porcine parthenogenetic and cloned embryos: comparison of oocyte-activating techniques, various culture systems and nuclear transfer methods. Reprod. Fert. Develop. 14, 93-99

Saito S., Yamakawa H., Nagashima H., 1992. Ability of porcine blastomere nuclei derived from 8- to 16-cell stage embryos to support development following transfer to enucleated oocytes in vitro. Assis. Reprod. Tech./Andro. 259, 257-266

Samiec M., Skrzyszowska M., Smorąg Z., 2003a. Somatic cloning in pigs; effect of activation treatments. Theriogenology 59, 286 (Abstr.)

Samiec M., Skrzyszowska M., Smorag Z., 2003b. Effect of activation treatments on the in vitro developmental potential of porcine nuclear transfer embryos. Czech J. Anim. Sci. 48, 499-507

Schoenbeck R.A., Peters M.S., Rickords L.F., Stumpf T.T., Prather R.S., 1992. Characterization of deoxyribonucleic acid synthesis and the transition from maternal to embryonic control in the 4-cell porcine embryo. Biol. Reprod. 47, 1118-1125

Schultz R.M., 1993. Regulation of zygotic gene activation in the mouse. Bioessays 15, 531-538

Sharma A., Martin M.J., Okabe J.F., Truglio R.A., Dhanjal N.K., Logan J.S., Kumar R., 1994. An isologous porcine promoter permits high level expression of human hemoglobin in transgenic swine. Biotechnology 12, 55-59

Shi W., Zakhartchenko V., Wolf E., 2003a. Epigenetic reprogramming in mammalian nuclear transfer. Differentiation 71, 91-113

Shi W., Hoeflich A., Flaswinkel H., Stojkovic M., Wolf E., Zakhartchenko V., 2003b. Induction of a senescent-like phenotype does not confer the ability of bovine immortal cells to support the development of nuclear transfer embryos. Biol. Reprod. 69, 301-309

Shiga K., Fujita T., Hirose K., Sasae Y., Nagai T., 1999. Production of calves by transfer of nuclei from cultured somatic cells obtained from Japanese black bulls. Theriogenology 52, 527-535

Shin T., Kraemer D., Pryor J., Liu L., Rugila J., Howe I., Buck S., Murphy K., Westhusin M., 2002. A cat cloned by nuclear transplantation. Nature 415, 859

Skrzyszowska M., Shioya Y., Nagai T., Geshi M., Tokenouchi N., 2000. Development of cloned bovine embryos from nuclei of cumulus and muscle cell origin. Theriogenology 53, 244 (Abstr.)

Surani A., 2001. Reprogramming of genome function through epigenetic inheritance. Nature 414, 122-128

Swanson M.E., Martin M.J., O’Donnell K.O., Hoover K., Lago W., Huntress V., Parsons C.T., Pinkert C.A., Pilder S., Logan J.S., 1992. Production of functional human hemoglobin in transgenic swine. Biotechnology 10, 557-559 
Tao T., Machaty Z., Boquest A.C., Day B.N., Prather R.S., 1999a. Development of pig embryos reconstructed by microinjection of cultured fetal fibroblast cells into in vitro matured oocytes. Anim. Reprod. Sci. 56, 133-141

Tao T., Boquest A.C., Machaty Z., Petersen A.L., Day B.N., Prather R.S., 1999b. Development of pig embryos by nuclear transfer of cultured fibroblast cells. Cloning 1, 55-62

Terlouw S.L., Prather R.S., Day B.N., 1992. In vitro development of nuclear transplant pig embryos. Theriogenology 37, 309 (Abstr.)

Thomson A.J., Marques M.M., McWhir J., 2003. Gene targeting in livestock. Reproduction 61, Suppl., 495-508

Tian X.C., Xu J., Yang X., 2000. Normal telomere lengths found in cloned cattle. Nature Genet. 26, 272-273

Uhm S.J., Chung H.M., Kim C., Shim H., Kim N.-H., Lee H.T., Chung K.S., 2000. In vitro development of porcine enucleated oocytes reconstructed by the transfer of porcine fetal fibroblasts and cumulus cells. Theriogenology 54, 559-570

Verma P.J., Du Z.-T., Crocker L., Faast R., Grupen C.G., McIlfatrick S.M., Ashman R.J., Lyons I.G., Nottle M.B., 2000. In vitro development of porcine nuclear transfer embryos constructed using fetal fibroblasts. Mol. Reprod. Dev. 57, 262-269

Vignon X., Chesne P., Le Bourhis D., Flechon J.E., Heyman Y., Renard J.-P., 1998. Developmental potential of bovine embryos reconstructed from enucleated matured oocytes fused with cultured somatic cells. Biol. Reprod., C.R. Acad. Sci. Paris, Life Sci. 321, 735-745

Vignon X., Zhou Q., Renard J.P., 2002. Chromatin as a regulative architecture of the early developmental functions of mammalian embryos after fertilization or nuclear transfer. Cloning Stem Cells 4, 363-377

Viuff D., Greve T., Holm P., Callesen H., Hyttel P., Thomsen P.D., 2002. Activation of the ribosomal RNA genes late in the third cell cycle of porcine embryos. Biol. Reprod. 66, 629-634

Wakayama T., Perry A.C.F., Zuccotti M., Johnson K.R., Yanagimachi R., 1998. Full-term development of mice from enucleated oocytes injected with cumulus cell nuclei. Nature 394, 369-374

Wakayama T., Yanagimachi R., 1999. Cloning of male mice from adult tail-tip cells. Nat. Genet. 22, 127-128

Wakayama T., Yanagimachi R., 2001. Mouse cloning with nucleus donor cells of different age and type. Mol. Reprod. Dev. 58, 376-383

Walker S.C., Shin T., Zaunbrecher G.M., Romano J.E., Johnson G.A., Bazer F.W., Piedrahita J.A., 2002. A highly efficient method for porcine cloning by nuclear transfer using in vitro-matured oocytes. Cloning Stem Cells 4, 105-112

Wang B., Zhou J., 2003. Specific genetic modifications of domestic animals by gene targeting and animal cloning. Reprod. Biol. Endocrinol. 1, 103

Wells D.N., Misica P.M., Tervit H.R., Vivanco W.H., 1998. Adult somatic cell nuclear transfer is used to preserve the last surviving cow of the Enderby Island cattle breed. Reprod. Fert. Develop. $10,369-378$

Wells D.N., Misica P.M., Tervit H.R., 1999. Production of cloned calves following nuclear transfer with cultured adult mural granulosa cells. Biol. Reprod. 60, 996-1005

Wilmut I., Schnieke A.E., McWhir J., Kind A.J., Campbell K.H.S., 1997. Viable offspring derived from fetal and adult mammalian cells. Nature 385, 810-813

Woods G.L., White K.L., Vanderwall D.K., Li G.P., Aston K.I., Bunch T.D., Meerdo L.N., Pate B.J., 2003. A mule cloned from fetal cells by nuclear transfer. Science 301, 1063

Wrenzycki C., Lucas-Hahn A., Herrmann D., Lemme E., Korsawe K., Niemann H., 2002. In vitro production and nuclear transfer affect dosage compensation of the X-linked gene transcripts G6PD, PGK, and Xist in preimplantation bovine embryos. Biol. Reprod. 66, 127-134 
Yamazaki Y., Makino H., Hamaguchi-Hamada K., Hamada S., Sugino H., Kawase E., Miyata T., Ogawa M., Yanagimachi R., Yagi T., 2001. Assessment of the developmental totipotency of neural cells in the cerebral cortex of mouse embryo by nuclear transfer. Proc. Natl. Acad. Sci. USA 98, 14022-14026

Yin X.J., Cho S.K., Park M.R., Cho H.Y., Im Y.J., Park J.J., Bhak J.S., Kim J.H., 2003. Production of cloned piglets by transfer of fetal fibroblasts into enucleated oocytes. Theriogenology 59, 294 (Abstr.)

Yin X.J., Tani T., Yonemura I., Kawakami M., Miyamoto K., Hasegawa R., Kato Y., Tsunoda Y., 2002. Production of cloned pigs from adult somatic cells by chemically assisted removal of maternal chromosomes. Biol. Reprod. 67, 442-446

Young L.E., Fernandes K., McEvoy T.G., Butterwith S.C., Gutierrez C.G., Carolan C., Broadbent P.J., Robinson J.J., Wilmut I., Sinclair D.S., 2001. Epigenetic change in IGF2R is associated with fetal overgrowth after sheep embryo culture. Nat. Genet. 27, 153-154

Young L.E., Sinclair K.D., Wilmut I., 1998. Large offspring syndrome in cattle and sheep. Rev. Reprod. 3, 155-163

Zakhartchenko V., Alberio R., Stojkovic M., Prelle K., Schernthaner W., Stojkovic P., Wenigerkind H., Wanke R., Düchler M., Steinborn R., Mueller M., Brem G., Wolf E., 1999a. Adult cloning in cattle: potential of nuclei from a permanent cell line and from primary cultures. Mol. Reprod. Dev. 54, 264-272

Zakhartchenko V., Durcova-Hills G., Stojkovic M., Schernthaner W., Prelle K., Steinborn R., Muller M., Brem G., Wolf E., 1999b. Effects of serum starvation and re-cloning on the efficiency of nuclear transfer using bovine fetal fibroblasts. J. Reprod. Fertil. 115, 325-331

\section{STRESZCZENIE}

\section{Rozwój badań nad klonowaniem świń: przeszlość, teraźniejszość i przyszlość}

Pierwsze sklonowane prosię uzyskano w wyniku transplantacji jądra komórki pochodzącej z zarodka 4-blastomerowego. Mimo, że w ostatnich latach odnotowano ogromny postęp w zakresie biotechnologii rozrodu świń, to na obecnym etapie badań wydajność technologii klonowania somatycznego świń jest ciaggle mniejsza niż u innych gatunków zwierząt gospodarskich i z reguły nie przekracza średnio 5 do $10 \%$ uzyskanych blastocyst oraz $1,5 \%$ urodzonych prosiąt w stosunku do liczby zrekonstruowanych oocytów. Podstawowym warunkiem praktycznego stosowania tej metody musi być zatem jej zadowalająca efektywność, co wymaga prowadzenia dalszych, szczegółowych badań.

Rozwój badań nad klonowaniem somatycznym świń, szczególnie w ostatnich latach, był podyktowany nie tylko koniecznością szybkiej poprawy skuteczności techniki transplantacji jąder komórkowych u tego gatunku, lecz przede wszystkim możliwością jej praktycznego zastosowania do multiplikacji transgenicznych prosiąt, ze względu na ważne implikacje w medycynie i immunologii transplantacyjnej, a także farmacji i hodowli zwierząt. Deficyt narządów do allotransplantacji u ludzi stał się bodźcem do poszukiwania nowych, alternatywnych źródeł przeszczepów. Dlatego też szczególnie atrakcyjną perspektywą klonowania somatycznego świń jest możliwość wykorzystania narządów transgenicznych świń w ksenotransplantacji z powodu ich porównywalnej z organami ludzkimi wielkości, anatomii, fizjologii, a także potencjalnie szerokiej dostępności. 